\title{
Danmarks Nationale Musikbibliotek ${ }^{1}$
}

af Erland Kolding Nielsen, direktor, Det Kongelige Bibliotek

Det Kongelige Bibliotek er i dag Danmarks Nationalbibliotek og Kobenhavns Universitetsbibliotek. Det kommer den dag i dag undertiden bag på folk - selv kulturpolitikere - at det, selv som nationalbibliotek, er langt mere end en samling af boger og tidsskrifter, til nod handskrifter og arkivalier, men ikke mindst gennem sine omfattende sarsamlinger af andre materialekategorier har bade centrale og vigtige museale, kulturelle og forskningsmassige opgaver og funktioner. ${ }^{2}$ Danmarks Bogmuseum kan som opgave og funktion spores langt bagud i tiden, og udstillinger har man haft siden 1908, fra 1945 med bredere kulturelt sigte. Det Nationale Fotomuseum grundlagdes i 1996 som en museal overbygning på Billedsamlingerne, Museet for Dansk Bladtegning $i$ 1998-99 i forbindelse med en omfattende national indsamling af bladtegninger. ${ }^{3} \mathrm{Gen}$ nem Haindskriftsamlingerne er man de facto Danmarks litteraturmuseum. ${ }^{4}$ Mindre koncerter er blevet foranstaltet siden 1980'erne, og det indgik i planlagningen 19861992 af udvidelserne $i$ Kobenhavns Havnefront, at netop de museale og kulturelle opgaver ud over nye faciliteter til forskningsbetjening og andre biblioteksformål skulle have serskilte faciliteter. 5

S om nationalbibliotek blev Det Kongelige Bibliotek oprindelig grundlagt af kong Frederik III (1648-1670) kort efter sin tronbestigelse i 1648. Det blev åbnet for offentligheden i 1793 og overgik til statseje som nationalbibliotek efter enevældens afskaffelse i 1848. Det fik tillagt funktionen som Københavns Universitetsbibliotek i 1927, og gennem en række fusioner med andre dele af det i 1482 grundlagte Universitetsbibliotek siden 1990 er Det Kongelige Bibliotek i dag både nationalbibliotek og det største universitetsbibliotek i Danmark og Nordeuropa. Dets bestand omfatter mere end 35 mio. fysiske enheder (ultimo 2014) på knap 200 hyldekilometer. Med den ikoniske nye bygning Den Sorte Diamant fra 1999 på Slotsholmen er der samtidig skabt enestående faciliteter for biblioteket som forsknings- og kulturinstitution, som ikke mindst musikopgaverne har fået stor gavn af.

Det Kongelige Bibliotek er gennem sine nationale samlinger og aktiviteter inden for musikvidenskab og musikudøvelse derfor også Danmarks Nationale Musikbibliotek. Dets virksomhed som sådan skal beskrives og dokumenteres i denne artikel med hovedvægt på tiden efter 1986.

\section{Samlinger}

Bibliotekets samlinger er i dag enestående både i henseende til omfang, dækningsgrad og betydning. Det gælder både ud fra en bevarings-, brugs- og kulturel synsvinkel. Der er i realiteten ikke andre substantielle musiksamlinger eller musikbiblioteker i Danmark. ${ }^{6}$ Historisk set har biblioteket delvis i medfør af pligtafleve- 
ringslovgivningen siden 1697 opbygget en komplet samling af bøger med noder ${ }^{7}$ og gennem køb og gaver erhvervet noder fra tidligere tider, indtil trykte noder som sådan blev inkorporeret i pligtafleveringen fra 1902. ${ }^{8}$ Erhvervelserne er siden foretaget inden for alle genrer og typer (middelalderlig, renæssance, klassisk, moderne, jazz, pop og rock), og biblioteket har tillige gennem 150 år suget node- og manuskriptsamlinger op ved institutions-, forenings- og orkesternedlæggelser, fået overdraget komponist-, privat- og forlagsarkiver og selv forestået indsamlingskampagner af manuskripter og andre nedslag af musikværker i nutiden. ${ }^{9}$ Endvidere rummer samlingerne nodetryk og manuskripter af udenlandsk proveniens, ${ }^{10}$ ligesom Håndskriftsamlingerne rummer papirer efter både danske og udenlandske komponister, musikere og videnskabsmænd. ${ }^{11}$ Musiksamlingens grundlæggelse kan sættes til 1813, ${ }^{12}$ om end den først blev organisatorisk udskilt som afdeling $\mathrm{i}$ 1878, og udvidet med teatersamlingerne i $2002 .{ }^{13}$

Således har biblioteket store samlinger af manuskripter og papirer, herunder breve, efter berømte komponister som f.eks. J.A. Scheibe (1708-1776), J.P.E. Hartmann (1805-1900), H.C. Lumbye (1810-1874), Niels W. Gade (1817-1890), Peter Heise (1830-1879), Carl Nielsen (1865-1931), ${ }^{14}$ Paul von Klenau (1883-1946), Rued Langgaard (1893-1952), Knudåge Riisager (18971974), Vagn Holmboe (1909-1996), ${ }^{15}$ Niels Viggo Bentzon (1919-2000), Per Nørgaard (f. 1931), og tillige betydelige samlinger efter bl.a. nordmanden Edvard Grieg (1843-1907), andre norske, svenske og finske komponister, ikke mindst pga. erhvervelsen i 1996 af arkivet efter det fællesnordiske musikforlag Wilhelm Hansen, ${ }^{16}$ hvortil kommer de ældre samlinger fra Det Kongelige Teater ${ }^{17}$ og i 1997 nodesamlingen på Ålholm Slot. ${ }^{18} \mathrm{I}$ nyere tid er der tilkommet store jazzsamlinger, især bestående af fonogrammer, ${ }^{19}$ ligesom Dansk Folkemindesamling, der genfusionerede med Det Kongelige Bibliotek i 2008, rummer store samlinger af noder, papirer og indspilninger vedr. folkemusik, bl.a. Evald Tang Kristensens (1843-1929) etnografiske optegnelser af folkelig vokalmusik 1867-1910 (noder og folkevisetekster), ${ }^{20}$ den store samling af bondespillemænds og musikamatørers egne, håndskrevne nodebøger i Danmark siden $1760,{ }^{21}$ en stor samling lyd- og videooptagelser med traditionelle musikog dansetraditioner i Danmark siden 1907 og Povl Rovsing Olsens (19221982) samlinger af etnografiske lydoptagelser fra Grønland og det arabiske område 1958-82.22

Ud over bøger og tidsskrifter, ${ }^{23}$ der jo primært indgår i hhv. de danske og udenlandske bogsamlinger, løber samlingerne af musikalier ultimo 2014 op i mere end 2.325 hyldemeter, i alt ca. 313.000 enheder, hvoraf ca. en trediedel er manuskripter. ${ }^{24}$ Mere end 6.500 heraf er retrodigitaliserede i Danmarks Digitale Nodebibliotek som digitale faksimiler af både nodetryk og -manuskripter. ${ }^{25}$

Musiksamlingerne er alle i dag katalogiseret eller registreret i bibliotekets enhedskatalog $\mathrm{REX}^{26}$ og beskrevet på hjemmesiden <www.kb.dk> i flere sammenhænge. ${ }^{27}$ Nationalbibliotekets Musik-og Teatersamling udarbejder de relevante dele af nationalbibliografien Dansk Musikfortegnelse, ${ }^{28}$ der nu i tre dele dækker alle nodeudgivelser siden 1899 , og hovedfagbibliografien Dansk Musiklit- 
terer Bibliografi indtil $1950^{29}$ og igen fra 1993. ${ }^{30}$ Som RISM-center for Danmark har den stået for bl.a. Musicat, fælleskatalogen over nodemanuskripter fra før år 1800 i danske offentlige samlinger inden for det internationale RISM-samarbejde (Répertoire Internationale des Sources Musicales).$^{31}$ Større tematisk-bibliografiske varkfortegnelser ${ }^{32}$ er allerede udarbejdet for H.C. Lumbye, ${ }^{33}$ Ruud Langgaard, ${ }^{34}$ Carl Nielsen, ${ }^{35}$ Niels Viggo Bentzon, ${ }^{36}$ Per Nørgård ${ }^{37}$ og internationale fortegnelser er under udarbejdelse for J.A. Scheibe, ${ }^{38}$ J.P.E. Hartmann ${ }^{39}$ og Niels W. Gade. ${ }^{40}$

\section{Orkesterbiblioteket og andre brugssamlinger}

Kort efter 2. verdenskrig oprettede biblioteket et særligt Orkesterbibliotek, der gennem årene har udviklet sig til den største samling af offentligt tilgængelige orkester- og korværker til praktisk opførelsesbrug i Norden og i dag omfatter ca. 8.000 trykte og ca. 12.000 håndskrevne opførelsesklare brugsnoder og stemmesæt, der for størstedelens vedkommende kan lånes. Det virker som national overcentral for musiklivet i Danmark, der benyttes intensivt af musikskoler, musikkonservatorier, professionelle og amatørorkestre og kor samt kammermusikensembler landet over, og som studiesamling for ældre orkestermusik og dramatisk musik..$^{41}$ I tilknytning til orkestersamlingerne har biblioteket igennem det seneste tiår skabt en stor udlånssamling af samlede praktiskvidenskabelige komponistudgaver i tilknytning til den komplette præsenssamling, der findes på centerlæsesalen $\mathrm{E}$ Vest. ${ }^{42}$ Inden for samme formidlingsgenre til praktisk brug kan nævnes katalogerne over Gieddes samling fortrinsvis af fløjtemusik, ${ }^{43}$ den verdensberømte Rischel
\& Birket-Smith-samling af guitarmusik $^{44}$ og en mindre over polsk musik fra det 20. århundrede..$^{45}$

Med indretningen af nye speciallæsesale (centerlæsesale) i Diamanten fik musik- og teaterområdet også en sådan med en referencesamling på åbne hylder på 25.000 bind omfattende bl.a. samtlige monument- og samlede værkudgaver, bibliografier, kataloger, værkfortegnelser, leksika, monografiske hovedværker m.v. Det er den største af sin art i Nordeuropa.

\section{Videnskabelige udgivelser og forskning} I 1990'erne tog det nationale musikbiblioteks funktioner som udgivelses- og forskningsinstitution fart ${ }^{46} \mathrm{ikke}$ mindst med udgivelsen af den store praktiskvidenskabelige udgave af Carl Nielsens samlede varker, der igangsattes gennem et politisk opdrag i 1993 og udkom i 52 bind 1998-2009 under (fra 1997) førstebibliotekar for Musik- og Teaterafdelingen, senere professor Niels Krabbes (f. 1941) ledelse, ${ }^{47}$ efterfulgt af Carl Nielsen Brevudgaven (udg. i 12 bind af John Fellow, f. 1947, 2005-2015) ${ }^{48}$ og senest den afsluttende tematisk-bibliografiske, digitale værkfortegnelse Catalogue of Carl Nielsen's Works (CNW) 2014. ${ }^{49}$ Carl Nielsen-arbejdet har endvidere omsat sig i det løbende årbogslignende periodicum Carl Nielsen Studies (5 bind 2003-2012) ${ }^{50}$ med omfattende bibliografier ${ }^{51}$ og en symposierapport om nordiske udgivelser og samarbejde. ${ }^{52}$ I 2011 fulgtes afslutningen på den praktisk-videnskabelige udgave op med afholdelsen af et internationalt Carl Nielsen symposium med titlen "Carl Nielsen. Inheritance and Legacy” på Det Kongelige Bibliotek. ${ }^{53}$

Ideen om løbende udgivelser fra samlingerne blev taget i 1993 med serien 

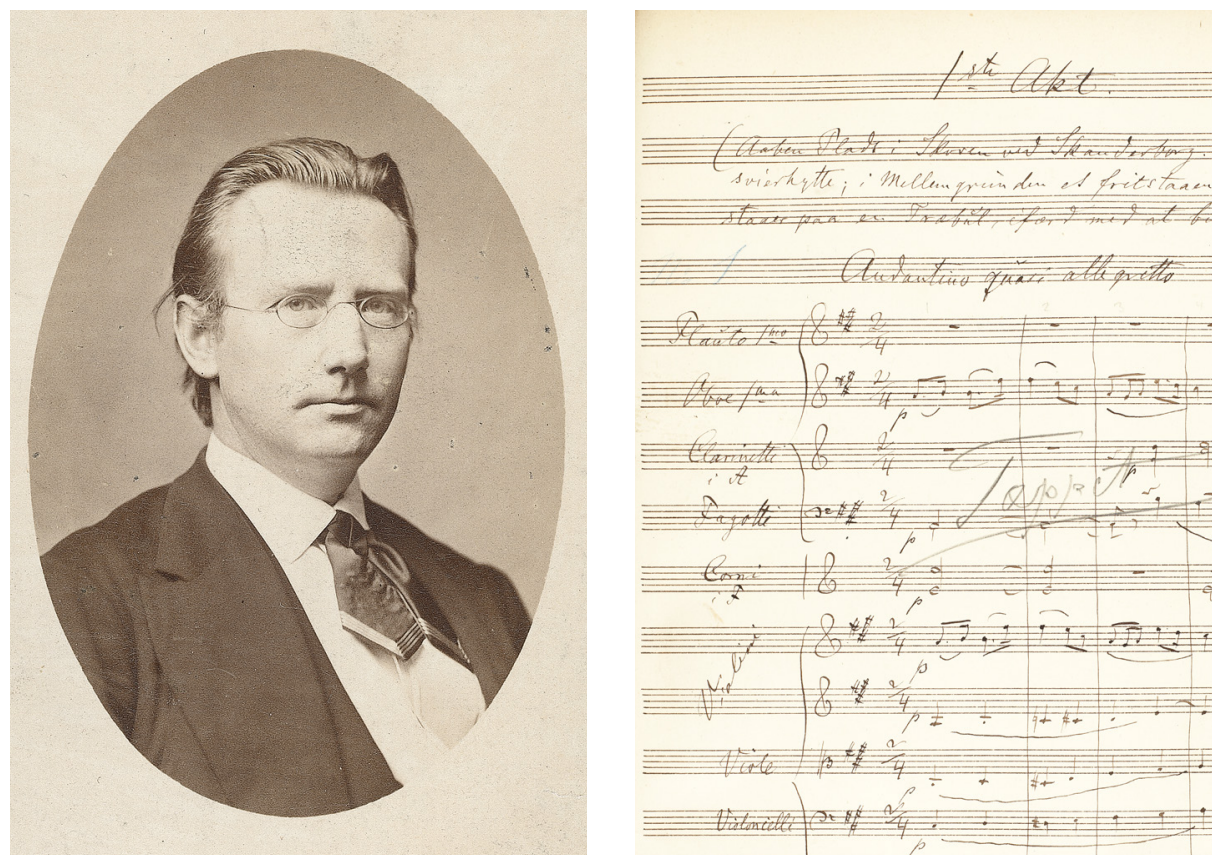

Trådene samles i bibliotekets samlinger. Fra venstre: komponist Peter Heise (Billedsamlingen); forste side i Heises egen renskrift af partituret til Drot og Marsk (Musiksamlingen); Emil Poul-

Dansk Musik fra Det Kongelige Biblioteks Samlinger (4 bind 1993-1997). ${ }^{54}$ Fra slutningen af 1990'erne udbyggedes udgivelserne med en selektiv monumentudgave over J.P.E. Hartmanns Verker (hovedredaktør Niels Krabbe, 7 bind siden 2002) $)^{55}$ og flere bind af den igangværende store praktisk-videnskabelige udgave af Niels W. Gades Verker (hidtil ca. 20 bind, hovedredaktør Finn Egeland Hansen, f. 1938, og Bo Foltmann, f. 1958 $)^{56}$ samt store brevudgaver over J.P.E. Hartmanns ( 4 bind 1999-2002), ${ }^{57}$ Niels W. Gades (3 bind 2008), ${ }^{58}$ og en mindre med C.F.E. Hornemans og Edvard Griegs korrespondance (2011) ${ }^{59}$ (alle udgivet af Inger Sørensen, f. 1944). Hertil kommer et omfattende udgivel- sesprogram med renæssancemusik fra det 15. og 16. århundrede i en række serier under titlen Capella Hafniensis Editions (udgivet af Ole Kongsted, f. 1943, 11 bind siden 2001)..$^{60}$

Tillige har biblioteket i $2010 \mathrm{i}$ anledning af Dronning Margrethes 70-års dag udgivet den ældste bevarede musik i Danmarkshistorien, musikken til hertug Knud Lavards helgenkåring i $1170,{ }^{61}$ der i 2012 blev fulgt op med et internationalt, videnskabeligt symposium om bl.a. de liturgiske og musikologiske aspekter heraf. ${ }^{62}$

To meget specielle udgivelser må også nævnes, nemlig udgivelsen i faksimile af Kronborgmotetterne fra 1582 i $1990^{63}$ fra fundet i St. Nikolai-kirken 

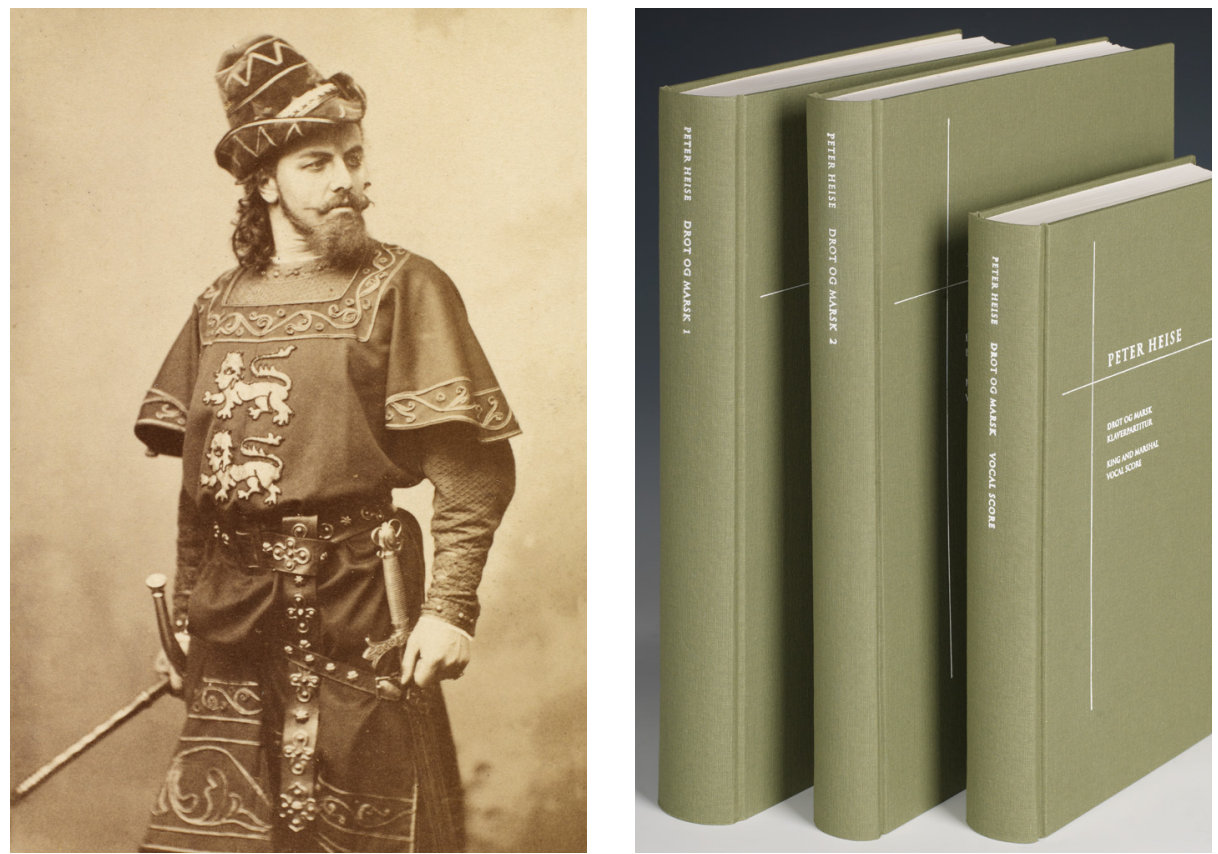

sen som kong Erik i forsteopforelsen på Det Kongelige Teater i 1878 (Teatersamlingen); den videnskabelige udgave fra 2012-13 (Dansk Center for Musikudgivelse / Forskningsafdelingen).

i Flensborg to år tidligere, ${ }^{64}$ og den mærkværdige musikalske stambog fra det 19. århundrede af den tyske violinist Heinrich Panofka (1807-1887), som biblioteket erhvervede i $1972 .{ }^{65}$

Endelig er der udgivet betydelige samlinger af tekster (artikler, essays og erindringer) af Carl Nielsen, ${ }^{66}$ Paul von Klenau, ${ }^{67}$ Knudåge Riisager ${ }^{68}$ og Per Nørgaard. ${ }^{69}$

Både tidligere og nuværende forskningsbibliotekarer samt tilknyttede forskere har tillige gennem årene i bibliotekets videnskabelige skriftserie Danish Humanist Texts and Studies udgivet en række større monografier og samleværker over enkelte komponister, musiklivets udvikling og musikken i skiftende perioder, således om Københavns koncertliv 1900-1935 (2002), ${ }^{70}$ musikteori (2006), ${ }^{71}$ Carl Nielsens sange (2010) ${ }^{72}$ kulturradikalismens musik (2013), ${ }^{73}$ komponisten og skribenten Knudåge Riisager (2015), ${ }^{74}$ samt to store festskrifter til henholdsvis førstebibliotekar Niels Krabbe (f. 1941), ${ }^{75}$ og professorerne John D. Bergsagel (f. 1928) og Heinrich W. Schwab (f. 1938), med hvem Det Kongelige Bibliotek har haft et tæt samarbejde gennem årene. ${ }^{76}$ Hertil kommer en omfattende artikelsamling om renæssancemusik i det baltiske område (2011), ${ }^{77}$ et større værk om musikteorien i England i det 17. århundrede ${ }^{78}$ og to store monografier udgivet i Dansk Folkemindesamlings regi om stadsmu- 
sikantvæsenet i Danmark 1660-1800 $(2000)^{79}$ og balladesang og kædedans (2015) ${ }^{80}$ En række nye forskningsprojekter om bl.a. høstning og bevaring af populærmusik i Netarkivet og komponistens rolle i samtidens kompositionsmusik er igangsat. ${ }^{81}$

I 2015 var Det Kongelige Bibliotek i samarbejde med det internationale Hanns Eisler Selskab i Berlin og Københavns Universitets Institut for Kunst og Kultur medarrangør af og vært for en international konference om kulturradikalismens musik $i$ et internationalt perspektiv. ${ }^{82}$

\section{Carl Nielsen Udgaven og Dansk Center for Musikudgivelse} Carl Nielsen Udgaven, der som en særligt organiseret enhed i Nationalbiblioteket omfattede 4-5 $\AA \mathrm{V}$ fra 1994, ${ }^{83}$ blev i 2009 efterfulgt af Dansk Center for Musikudgivelse med bredere opgaver inden for musikfilologi, -udgivelse og -forskning, ${ }^{84}$ hvortil oprettedes det første musikvidenskabelige professorat uden for danske universiteter, finansieret af Lundbeck Fonden $\mathrm{i} 4$ år. Den første leder og professor blev Carl Nielsen Udgavens chefredaktør Niels Krabbe. Centret oprettedes for en 5-årig periode 2009-2014, og blev sidste år forlænget for årene 2014-2019, nu under ledelse af Axel Teich Geertinger. Dets udgivelser kan erhverves mod betaling i trykt form on demand eller frit downloades fra Centrets hjemmeside. ${ }^{85}$ Det er det eneste center af sin art i verden. ${ }^{86}$

\section{Operaudgivelser}

Blandt tyngdepunkterne i Det Kongelige Biblioteks praktisk-videnskabelige udgivelsesvirksomhed har stået udgivelsen af de største og mest betydningsfulde danske operaer i internationale, opførelsesklare udgaver. Gennem de sidste 15 år er der således udgivet fire, nemlig Carl Nielsens Maskarade (1904-06, parallelle dansktyske og dansk-engelske udgaver 1999) og Saul og David (1898-1901, parallelle dansk-tyske og dansk-engelske udgaver 2003), J.P.E. Hartmanns opera Liden Kirsten (med libretto af H.C. Andersen på dansk og tysk 1846, udgivet 2005), ${ }^{87}$ indtil Carl Nielsens Maskerade opfattet som nationaloperaen og stadig den mest opførte danske opera gennem tiderne, og endelig Peter Heises Drot og Marsk (1878, dansk-engelsk udgave 2012-13). ${ }^{88}$ Inden for rammerne af Dansk Center for Musikudgivelse planlægges C.F.E. Hornemans Aladdin (1888/1902) ${ }^{89}$ Det er en enestående præstation i dansk musikudgivelseshistorie. $^{90}$

\section{Formidling af samlinger og musik}

I 1999 udvidedes Det Kongelige Bibliotek med en ny bygning, den tredje i det nuværende kompleks på Slotsholmen over for Christiansborgs Slot, der huser Folketinget, Statsministeriet og Højesteret, med det ikoniske tilnavn Den Sorte Diamant. Bygningen indeholder bl.a. en koncertsal med 400-500 tilhørerpladser, foredragssale, samt et Center for Musik og Teater med en stor referencesamling på ca. 25.000 bind på åbne hylder. Hermed udvidedes det nationale musikbiblioteks mulighed for formidling på musikområdet $i$ et omfang uden sidestykke andetsteds.

Efter en kort periode med en strygekvartet in residence ${ }^{91}$ grundlagdes i 2004 et særligt kammermusikensemble DiamantEnsemblet med 5 strygere, 5 blæsere og (fra 2014) en pianist, sponsoreret af det store firma Siemens Danmark og med støtte fra 3 danske fonde. ${ }^{92}$ Ensemblet gi- 
ver 7-9 koncerter årligt i Dronningesalen, nationalbibliotekets koncertsal, og dets sammensætning giver rige variationsmuligheder inden for et bredt kammermusikalsk repertoire over tre århundreder. Ikke mindst ensemblets nytårskoncert er et hit.

Herudover foranstalter Kulturafdelingen i samarbejde med Musiksamlingen, DCM og en række eksterne samarbejdspartnere en lang række yderligere koncerter, i vid udstrækning ud fra en musikpolitik, der blev fastlagt allerede før Diamantens indvielse og siden er revideret løbende. Blandt musikpolitikkens oprindelige hovedpunkter var naturligvis promovering af nyfundne eller mindre kendte værker fra samlingerne som et bidrag til udvidelse af koncertrepertoiret inden for kulturarven under betegnelsen "udstillingskoncerter". Bibliotekets Kulturafdeling har foranstaltet forsøg med nye koncertformer, etableret en række koncertserier m.v.

I Carl Nielsen-året 2015 foranstaltede biblioteket i samarbejde med Det Kongelige Danske Musikkonservatorium og Danmarks Radio den første Internationale Carl Nielsen Kammermusikkonkurrence for strygekvartetter og blaserkvintetter for 20 udvalgte unge ensembler med en gennemsnitsalder på under 30 år, hvor den indledende runde foregik på konservatoriet, semifinalerne i Dronningesalen og finalerne i DR's koncertsal. ${ }^{93}$

Dronningesalen har i en række tilfælde i samarbejde med Kulturafdelingen været benyttet til indspilninger af værker, ${ }^{94}$ f.o.f. i forbindelse med bibliotekets udgivelser ${ }^{95}$ eller af DiamantEnsemblet. ${ }^{96}$

Som et supplement til koncertsalen er der indbygget et 12-kanal-system til elektroniske koncerter i Diamantens atrium. Igennem mange år har den danske kom- ponist Fuzzys (f. 1939) store elektroniske musikværk Katalog (over Det Kongelige Biblioteks skatte, 2002-3) i 52 korte satser - én til hver uge året rundt - være opført dagligt kl. 13:00.9 I anledning af Dansk Komponistforenings 100-års jubilæum opførtes her nye kompositioner af 6 unge danske komponister, skrevet til anlægget. Fra 2015 er komponisten, professor Wayne Siegel (f. 1953) knyttet til biblioteket som huskomponist i elektronmusik, finansieret af Musikrådet.

En anden form for formidling er Dansk Folkemindesamlings temadage med fokus på aktuelle kulturelle temaer inden for musik, hvor resultaterne af medarbejdernes forskning formidles i form af offentlige foredrag. Der har været afholdt seminarer over "Musik og danskhed" 2003,98 "Min musik, din musik. Hvad betyder musik for mennesker?" $2010^{99} \mathrm{og}$ "Musik som identitet" i 2015. ${ }^{100}$

2009 dannede Det Kongelige Bibliotek sammen med Odense Bys Museer (bl.a. Carl Nielsen Museet) det danske Carl Nielsen Netverk, en sammenslutning af danske institutioner inden for musiklivet, der bl.a. har organiseret en lang række nationale og internationale aktiviteter i forbindelse med 150-året for Carl Nielsens fødsel i 1865 og i den forbindelse fra 2014 har skabt den fælles hjemmeside <www.carlnielsen.org> med oversigter over aktiviteter, koncerter, udgivelser, adgang til noder etc. Ud over tidligere nævnte udgivelser, koncerter og vandreudstillinger ${ }^{101}$ udgav biblioteket $\mathrm{i}$ samarbejde med det statslige pladeselskab Dacapo cd'en The Unknown Carl Nielsen til promovering fortrinsvis i udlandet af Nielsen som sangkomponist i et uhørt stort oplag. ${ }^{102}$ Netværket ophævedes efter at have løst sine opgaver, men i november 
2015 har Det Kongelige Bibliotek taget initiativ til at danne et nyt til koordination af aktiviteter og fejring af Danmarks anden store, internationalt berømte komponist Niels W. Gade, der i 2017 fylder 200 år.

\section{Udstillinger}

Det Kongelige Biblioteks udstillingsvirksomhed tog sin begyndelse i 1908, hvor der i en særlig indrettet udstillingssal i Galleriet over forhallen (Oktogonen) i Holms bygning vistes en stor, fast udstilling med 886 genstande, heriblandt mange musikalier. ${ }^{103}$ Udstillingen nedlagdes ved 2 . verdenskrigs udbrud ${ }^{104}$ og blev aldrig genetableret, og galleriet inddroges til magasin- og kontorformål indtil begyndelsen af 1990'erne. Fra omkring 1950 etableredes skiftende (sær) udstillinger i selve forhallen, og musikområdet var naturligvis repræsenteret fra tid til anden, således med udstillinger om Johann Sebastian Bach i anledning af 200-årsdagen for hans død 1950, ved Thomas Laubs 100-års fødselsdag 1952, Carl Nielsen 1953, om H. \& Fr. Rungs musikarkiv 1955, J.P.E. Hartmann ved 150-årsdagen 1955, om G.F. Händel, Joseph Haydn \& Felix Mendelssohn Bartholdy 1959, Robert Schumann ved 150-årsdagen 1960, F.L.Ae. Kunzen ved 200-årsdagen 1961, Christoph Willibald Gluck ved 250-årsdagen i 1964, Carl Nielsen igen ved 100-årsdagen 1965, om Det Kongelige Danske Musikkonservatorium gennem 100 år 1966, Niels W. Gade ved 150-årsdagen 1967, Ludvig van Beethoven ved 200-årsdagen 1970, en sommerudstilling om "Musik i Danmark" 1972, C.E.F. Weyse ved 200-årsdagen 1974, J.A. Scheibe i 200 -året for hans død 1976, ${ }^{105}$ Niels W. Gade i 100-året for hans død 1990, ${ }^{106}$ W.A. Mozart i 200-året for hans død 1991, ${ }^{107}$ Ruud Langgaard ved 100-årsdagen $1993,{ }^{108}$ og F.L.Ae. Kunzen (1761-1817) i anledning af 200-året for hans udnævnelse til dansk hofkapelmester $1995 .{ }^{109}$ Derefter lukkedes for udstillinger her indtil indvielsen af Diamanten i september 1999. I stedet viste en række udstillinger andetsteds, således om Knudåge Riisager ved 100-årsdagen 1997 på Musikhistorisk Museum \& Carl Claudius' Samling. ${ }^{110}$ I 1990 havde Det Kongelige Bibliotek endvidere i samarbejde med Dansk Selskab for Musikforskning og Det nationalhistoriske Museum på Frederiksborg arrangeret en udstilling om renaissancemusik på Frederiksborg i anledning af Dronning Margrethes 50-års fødselsdag ${ }^{111}$ og udgivelsen af Kronborgmotetterne fra Flensborgfundet to år tidligere i faksimile. ${ }^{12}$

Med de nye udstillingssale, f.o.f. Søjlesalen på $300 \mathrm{~m}^{2}$ i Diamanten, fik udstillingsvirksomheden nye muligheder, men kravene voksede også tilsvarende både kvantitativt, design- og indholdsmæssigt. Store musikudstillinger har været vist i 2000, 2004, 2007 og 2009. Den første i Diamanten var om J.P.E. Hartmann i $2000 \mathrm{i}$ anledning af 100-året for hans død. ${ }^{113}$ I 2004 vistes en stor udstilling om dansk-tyske musikrelationer indtil 1914 i Paulinerkirken i Göttingen, ${ }^{114}$ som blev gentaget i revideret udgave i Diamanten i foråret $2007,{ }^{115}$ og i 2009 vistes en udstilling om Carl Nielsen i anledning af afslutningen på den samlede, praktiskvidenskabelige udgave af hans værker. ${ }^{116}$

\section{Afslutning}

Som nationalt musikbibliotek har Det Kongelige Bibliotek ved særlige lejligheder også bestilt musikværker hos nule- 
vende komponister, således til fejringen af 200-året som offentligt nationalbibliotek i november $1993,{ }^{117}$ til indvielsen af den nye bygning, Den Sorte Diamant, i september $1999,{ }^{118}$ indvielsen af det store 12-kanals højtaleranlæg i Diamantens forhal januar $2002 \mathrm{i}$ anledning af årtusindskiftet, ${ }^{119} \mathrm{og}$ i forbindelse med erhvervelsen af komponisten Bo Holtens manuskript og papirer til operaen Livlagens besøg en strygekvartet af samme. ${ }^{120}$

\section{Noter}

1 Denne artikel er en udvidet version af undertegnedes artikel "The Royal Library - The National Music Library of Denmark", I: The Unknown Carl Nielsen. Danish Songs in English. [Booklet til cd af samme navn] Udg. af Det Kgl. Bibliotek \& Dacapo Records, 2015, ss. 17-20. Den omhandler f.o.f. udviklingen i forfatterens egen embedstid. For Musikafdelingen i tidligere perioder, se Sven Lunn: "Opbygningen af Det kongelige Biblioteks Musiksamling", Biblioteksaarbog, 7, 1946, ss. 4050; Erik Dal: "Peter Grønland 1761-1825. En holstensk musikdyrker i København", Fund og Forskning i Det Kongelige Biblioteks Samlinger, 7, 1960, ss. 100-124 [om Grønlands og Weyses samlinger]; Harald Ilsøe: "Musikalier", På Papir, Pergament og Palmeblade - Skatte i Det Kongelige Bibliotek. Det Kongelige Bibliotek. 1993, ss. 315-328. Musik-, senere Musik- og Teaterafdelingens virksomhed og udvikling kan siden 1993 følges i afdelingens afsnit i Det Kongelige Biblioteks Årsberetninger, der blev indstillet med 1946/47, udg. i 1952, men genoptoges i 1993; dertil kommer en lang række såkaldte "Fokusartikler", dvs. selvstændige uddybninger af særlige emner som erhvervelser, udgivelser, begivenheder
Det Kongelige Bibliotek er samlet set Nordeuropas rigeste musikbibliotek i henseende til samlinger, og med hensyn til forsknings- og formidlingsaktiviteter er det også enestående i Europa. Hovedparten af disse aktiviteter er konciperet og udviklet i den seneste menneskealder, ikke mindst i forbindelse med den store udbygning på Københavns Havnefront, der blev planlagt 1986-1993 og gennemført frem til 1999. ${ }^{121}$

og løbende om Carl Nielsen Udgaven 1998-2009 og Dansk Center for Musikudgivelse. De relevante fokusartikler er alle anført i noterne.

Jeg takker en række medarbejdere ved Det Kongelige Bibliotek for kommentarer og rettelser, først og fremmest seniorkonsulent Anne Ørbæk Jensen, seniorforsker Jens Henrik Koudal \& professor emer. Niels Krabbe. Ansvaret for eventuelle fejl og mangler er dog alene mit.

2 Se også mit forord til Ingrid Fischer Jonge: Fotografi i Diamanten. Udvalgte varker fra Det Nationale Fotomuseum. Det Kongelige Bibliotek, 2004, s. $7 \mathrm{f}$.

3 Se bl.a. Julie Fryd Johansen: "Museet for Dansk Bladtegning”, Arsberetning 2000, 2001, s. $49 f$.

4 Se i forhold hertil Niels D. Lund: "En stor litteraturinstitution: Deutsches Litteraturarchiv Marbach", Magasin fra Det Kongelige Bibliotek, årg. 27:1, 2014, ss. 33-46.

5 Se Arsberetning 1999, 2000, passim; Erland Kolding Nielsen: “'A New Role for the Royal Library' Transforming a National Library for a Wider World", Arsberetning 2000, 2001, ss. 188-194; The Architecture of the Royal Library / 
Det Kongelige Biblioteks arkitektur. Udg. af schmidt hammer lassen architects. 2. udg. 2011, især afsnittene "Description / Beskrivelse" [af bygningen, dens principper, indretning og funktioner] ss. 10-13, og Erland Kolding Nielsen: "Postscript / Efterskrift" [om ideer, koncept og udvikling af opgaver i det første årti], ss. 131-37; desuden en række af artiklerne i afsnittet "Kulturforvaltning" i: Umisteligt. Festskrift til Erland Kolding Nielsen. Red. af John T. Lauridsen \& Olaf Olsen. Det Kongelige Bibliotek: Museum Tusculanums Forlag, 2007, ss. 477-731.

6 Det Kongelige Danske Musikkonservatorium besidder dog en stor brugssamling af noder, og Statsbiblioteket har ligeledes siden 1902 haft et sekundært brugseksemplar af alle trykte noder. Blandt musikkonservatoriebiblioteker har især Det Kongelige Danske Musikkonservatorium et betydeligt brugsbibliotek, og Musikmuseet (tidl. Musikhistorisk Museum og Carl Claudius' Samling) har både et mindre bibliotek og en samling af arkivalier.

7 Ud over at være registreret i Bibliotheca Danica og bibliotekets kataloger er trykte danske musikalier registreret i Dan Fog: Dansk Musikfortegnelse. En dateret katalog over trykte danske musikalier. 1. del: 17501854. Dan Fog Musikforlag. 1979, $204 \mathrm{s.}$ med yderligere henvisninger til kataloger og bibliografier før $1750 \mathrm{og}$ frem til 1899. For fortsættelserne, se ndf.

8 Pligtafleveringen for selvstændige nodetryk (musikalier) indførtes først fra dette år, men KB havde naturligvis indsamlet og erhvervet nodetryk tidligere, se Knud Arne Jürgensen: "(Af)levering af musiktryk i Danmark - i lyst, pligt og nød”, i: Den trykte kulturarv. Pligtaflevering gennem 300 arr. Red. af Henrik Horstbøll og John T. Lauridsen. Det Kgl. Bibliotek \& Statsbiblioteket: Museum Tusculanums Forlag, 1998, ss. 169-194 (Danish Humanist Texts and Studies, vol. 16).
9 Siden ca. 1970 har biblioteket henvendt sig til nulevende komponister for at erhverve deres originalmanuskripter. Efter tidligere tilløb blev indsamlingen sat i system af dav. førstebibliotekar, mag. art Eva Brit-Fanger, førstebibliotekar 1969-1996, og fortsat af cand.mag. Niels Krabbe, førstebibliotekar 1996-2009, derefter forskningsprofessor 2009-2013, og cand. mag. Anne Ørbæk Jensen, førstebibliotekar 2009-2013, nu seniorkonsulent.

10 For et fremtrædende eksempel se: Krabbe, Niels: "Fra Beethovens skrivepult i Wien til magasinerne i København. En manuskriptkopi af Beethovens Missa solemnis i Det Kongelige Bibliotek", Magasin fra Det Kongelige Bibliotek, 2013:4, ss. 3-21.

11 Se REX samt for accessionen 1924-1987: Det kongelige Biblioteks Haindskriftafdeling. Erhvervelser 1924-1987. Vejledning $i$ benyttelse. Red.: Birgitte Possing og Bruno Svindborg. Det kongelige Bibliotek: Museums Tusculanums Forlag. 1995. Bd. 1-2. 677 s. (Danish Humanist Texts and Studies 12); en særlig registrant over musikrelevante kilder er: Nanna Schiødt, Dan Fog \& Hans Danelund: Hagens Samling i Det kongelige Biblioteks Håndskriftafdeling. Kilder til dansk musikhistorie samlet af S.A.E. Hagen. Det kongelige Bibliotek. 1981, 167 s. Ill. (Specialhjalpemidler 4).

12 Med købet af kgl. kapelmusikus J.H. Lorentz' samling af musikalier og musiklitteratur og konsolideret med erhvervelserne efter musikelskeren Peter Grønlunds efterladenskaber (se ovf. note 1), komponisten C.E.F. Weyses samling i 1842 , det nye Hofmusikarkiv (grundlagt efter branden i 1794) med kammerherre Gieddes samling i 1903 (se ndf. note 43), Det Kgl. Teaters ældre musikaliesamlinger i flere omgange fra 1905 (se ndf. note 17), Henrik og Frederik Rungs musikarkiv 1955, Rischel \& Birket Smiths samling 1957 (se ndf. note 44), Dan Fogs samlinger i 1993, Mogens Ellegaards samlinger i 1996, Forlaget 
Wilhelm Hansens arkiv 1996 (se ndf. note 16), og senest Ålholmssamlingen 1997 (se ndf. note 18), se generelt <www.kb.dk/ $\mathrm{da} / \mathrm{nb} /$ samling/ma/noder/pers.html $>$.

13 Se Arsberetningerne 2002ff., $2003 \mathrm{ff}$.

14 Bjørnum, Birgit \& Klaus Møllerhøj: Carl Nielsens Samling / The Carl Nielsen Collection. Katalog over komponistens musikhaindskrifter i Det kongelige Bibliotek / A Catalogue of the Composer's Musical Manuscripts in the Royal Library. Det kongelige Bibliotek : Museum Tusculanums Forlag. 1992. 275 s. (Danish Humanist Texts and Studies, vol. 4), samt den tematisk-bibliografiske, digitale værkfortegnelse Catalogue of Carl Nielsen's Works (CNW) 2014, jf. ndf.

15 Se [Erland Kolding Nielsen:] "Komponisten Vagn Holmboes efterladte manuskripter", Arsberetning 2000, 2001, s. 55 f. (optryk fra Kulturverdiudvalgets ärsberetning s.å.)

16 Se [Erland Kolding Nielsen:] "Familien Wilhelm Hansens Arkiv”, Arsberetning 1996, 1997, ss. 27-31 (optryk fra Kulturverdiudvalgets årsberetning s.å.)

17 I 1905 modtog Det Kongelige Bibliotek 906 ældre partiturer fra Det Kongelige Teater, der i 1936, 1945 og 1983 blev suppleret med yderligere partiturer samt orkester- og korstemmer. Samlingen går helt tilbage til 1700-tallet og omfatter desuden opførelsesmateriale til en lang række af 1800-tallets og 1900-tallets kendteste danske og udenlandske musikdramatiske værker. Derudover findes kantater og korværker fra omkring 1800, oprindelig fra det nye Hofmusikarkiv, der indlemmedes i bibliotekets samlinger i 1903. Samlingen er nu registreret i REX.

18 Fundet i 1991 af nuv. seniorforsker, dr.phil. Jens Henrik Koudal, Dansk Folkemindesamling. Se Jens Henrik Koudal: "Nodefundet på Aalholm Slot. En kort præsentation”, Cecilia, 1992-93, ss. 265-278, og [Erland Kolding Niel- sen:] "Nodesamlingen på Ålholm Slot", Ärsberetning 1997, 1998, s. 36f. (optryk fra Kulturvardiudvalgets årsberetning s.å.)

19 Se Niels Krabbe: "Jazzsamlinger", Arsberetning 2008, 2009, s. 55f. Erhvervelserne omfatter f.o.f. Arkiv for Dansk Jazzhistorie (fra dr.phil. Erik Wiedemann), Lindemanns Samling, Arnvid Meyers og dele af Karl Emil Knudsens samlinger.

20 Se om hans samlinger generelt: Jens Henrik Koudal: Folkeminder og dagliglivets kultur. Indforing i Dansk Folkemindesamlings arkiv. Kbh.: C.A. Reitzels Forlag. 2004, ss. 65-72.

21 Se om "Viser, sange og sanglege", sst. ss. 118-137, "Instrumentalmusik", ss. 143154 samt passim.

22 Se om "Lydarkivet", sst., ss. 194-222.

23 Se for disse også Eva-Brit Fanger: Katalog over musiktidsskrifter $i$ danske forskningsbiblioteker. Det kongelige Bibliotek. 1997, 118 s. (Specialhjalpemidler bd. 33). Omfatter 1.786 titler, der udgør Danmarks bidrag til International Association of Music Libraries' (IAML) fælleskatalog over musiktidsskrifter, se videre RIPM, Retrospective Index to Music Periodicals 1800-1950, se < www.kb.dk/da/nb/nyheder/mta/ breve2008/0805ripm.html>.

24 Udviklingen kan gennem de seneste knap 30 år følges statistisk i Det Kongelige Biblioteks Arsberetninger 1993ff., hvor der hvert år findes en ajourført 5-, fra 2013- en 4-års retrospektiv statistik over bibliotekets ydelser, bestandsudvikling og tilvækst, fordelt på materialekategorier, registrering til kataloger, national-, fag- og specialbibliografier, kulturelle aktiviteter, bl.a. udstillinger og koncerter, forskning m.m. For musikdatabaser internationalt, se <www.kb.dk/da/materialer/e-ressourcer/ databaser/oldindex.html?subject=roothumanities-music\&q $=\&$ sort $=$ relevance $>$.

$25 \mathrm{Se}<$ www.kb.dk/da/nb/samling/ma/ digmus $>$ og < www.kb.dk/da/nb/samling/ $\mathrm{ma} /$ digmus/musem.html $>$. 
26 Man kan søge særskilt i "Musiksamlingen" eller afgrænse søgningen til de enkelte dele eller samlinger i denne, således "Trykte noder", "Digitale noder", "Musikhåndskrifter", "Orkesterbiblioteket", "Fonogrammer", "Rischel \& Birket-Smiths Samling", "Gieddes Samling," "Aalholm Samlingen", "MUSICAT" og til national-ogfagbibliografierne "Dansk Musikfortegnelse 19311971", “Dansk Musikfortegnelse 1972 ff., "Dansk Musiklitterær Bibliografi”. "Dansk Musikfortegnelse 1899-1930” er ikke i REX, men kan findes via hjemmesiden. Specielt skal det påpeges, at inden for de sidste 15 år er den enorme samling af $m u$ siksmåtryk fra det 19. og 20. århundrede, $i$ alt mere end 35.000 enheder $(42 \mathrm{hm})$, også blevet individuelt katalogiseret, se den digitale oversigt over alle kategorier: "Danske noder til populærmusik er nu færdigregistreret " < www.kb.dk/da/nb/ nyheder/mta/breve2011/1102smaatryk. html>.

27 Se Musikmaterialer under <www.kb.dk/ $\mathrm{da} / \mathrm{nb} / \mathrm{materialer} / \mathrm{musik}>$, Musiksamlingerne under <www.kb.dk/da/nb/ samling/ma>, enkelte Nodesamlinger under <www.kb.dk/da/nb/samling/ $\mathrm{ma} /$ noder $>$, Musikarkiver under <www. $\mathrm{kb} . \mathrm{dk} / \mathrm{da} / \mathrm{nb} /$ samling/ma/arkiver $>$, Søge- og emneguides under <www.kb.dk/ $\mathrm{da} / \mathrm{nb} /$ samling/ma/guides $>$, over 75 Fokussider under <www.kb.dk/da/nb/ samling/ma/fokus $>$ og < wayback-01. $\mathrm{kb} . \mathrm{dk} /$ wayback/20101103150301/ www2.kb.dk/kb/dept/nbo/ma/fokus>, Indspillet musik under <www.kb.dk/da/ $\mathrm{nb} /$ samling/ma/fon $>$.

28 Se dens "landing page" <www.kb.dk/da/ $\mathrm{nb} /$ samling/ma/om/dm $>$.

$29 \mathrm{Se}<\mathrm{www} \cdot \mathrm{kb} \cdot \mathrm{dk} / \mathrm{da} / \mathrm{nb} / \mathrm{sam}$ ling/ma/om/ damuslit.html $>$.

30 Dansk Musiklitterer Bibliografi udarbejdes årligt af Anne Ørbæk Jensen og materialet publiceres i fire sammenhænge i forskelligt udvalg og afgrænsning:
- "Bibliography" i Danish Yearbook of Musicology medtager materiale fra danske forskere og/eller om danske musikforhold. Seneste udk. årgang er vol. 39, 2012, der udgiver bibliografien for 2011. Bibliografien er bragt i årbogen siden 1993.

- Dansk Musiklitterer Bibliografi som en base i REX. Grundlaget er Sigurd Bergs danske musiklitterære bibliografi over perioden indtil 1950, der blev overført til REX i 2002, og suppleret med indførslerne fra bibliografien $\mathrm{i}$ årbogen fra 1993 og p.t. til og med 2012. Der er enkelte supplementer $\mathrm{i}$ basen i forhold til årbogen. Basen omfatter (2015) ca. 19.700 poster.

- Répertoire Internationale de la Littérature Musicale (RILM), der omfatter publikationer, offentliggjort i Danmark, herunder publikationer af udenlandske forskere om forhold, der ikke specielt er tilknyttet Danmark, men publiceret her. RILM udvælger og indlægger selv mange af registreringerne, således at det danske bidrag er noget uegalt, mht. hvor mange poster, det danske bidrag omfatter. Se herom den danske side: <www.rilm.org/ globalNetwork/Denmark.php>.

- Recent Publications in Music: Den internationale musikbiblioteksforening, IAML, udgiver en online fortegnelse over boger og ph.d-afhandlinger fra en række lande. Det Kongelige Bibliotek bidrager med et udtræk af bøger og afhandlinger fra Danmark: <www. iaml.info/recent-publications-music $>$. Fortegnelsen publiceres også i foreningens tidsskrift Fontes Artis Musicae.

$31 \mathrm{Se}<$ www.kb.dk/da/nb/samling/ma/om/ damuslit.html $>$. Basen indeholder ca. 1 mio. poster, overvejende fra efter 1600 og før 1850, og ca. 25.000 komponister er repræsenteret. Det Kongelige Bibliotek og andre musiksamlinger i Danmark er 
repræsenteret i basen med $i$ alt ca. 5.000 registreringer helt overvejende fra før 1800; kun manuskripter i Weyses samling efter 1800 er blevet registreret.

32 Se for en fortegnelse over værkfortegnelser for danske komponister, <www.kb.dk/da/ $\mathrm{nb} /$ samling/ma/guides/vaerk.html>.

33 Dan Fog: Lumbye-katalog. Fortegnelse over H.C. Lumbys trykte kompositioner / Verzeichnis der gedruckten Kompositionen von H.C. Lumbye (1810-1874). Det Kongelige Bibliotek: Museum Tusculanums Forlag. 1995, 176 s. (Danish Humanist Texts and Studies, vol. 10), og Knud-Arne Jürgensens web-værkfortegnelse <www. $\mathrm{kb} . \mathrm{dk} / \mathrm{da} / \mathrm{nb} / \mathrm{samling} / \mathrm{ma} /$ noder/pers. html>.

34 Bendt Viinholt Nielsen: Rued Langgaards Kompositioner. Annoteret verkfortegnelse / Rued Langgaard's Compositions. An Annotated Catalogue of Works. Odense Universitetsforlag. 1991, $561 \mathrm{s.}$

35 Se ndf., note 49. En trykt referenceudgave udsendes i 2016 i serien Danish Humanist Texts and Studies.

36 Klaus Møllerhøj: Niels Viggo Bentzons Kompositioner. En fortegnelse over varkerne med opusnummer. Det Kongelige Bibliotek: Edition Wilhelm Hansen. 1980, 160 s. Omfatter til og med opus 429, 1979.

37 Ivan Hansen: Per Norgärds kompositioner. Kronologisk varkfortegnelse 1949-2012. 2012. Digitalt publiceret, se <www. $\mathrm{kb} . \mathrm{dk} / \mathrm{da} / \mathrm{nb} / \mathrm{dcm} /$ udgivelser/norgard/ vaerkliste.html>. Inkorporerer Birgit Bjørnum: Per Nørgårds Kompositioner. En kronologisk-tematisk fortegnelse over varkerne 1949-1982. Det Kongelige Bibliotek: Edition Wilhelm Hansen, 1983.

38 Ved seniorforsker, ph.d. Peter Hauge, se <www.kb.dk/da/nb/dcm/projekter/ scheibe $>$.

39 Ved tidl. seniorforsker, cand.phil. Inger Sørensen. Udkommer i 2016 i både bogform og digital udgave.

40 Ved samme. Planlagt til udgivelse i 2017.
41 Se < www.kb.dk/da/nb/samling/ma/ noder/ork>. I 1993 udgaves en Orkesterkatalog. Symfoniorkester - Strygeorkester - Kammerorkester - Kor. Udarb. og red. af Kurt Ferré Andersen. [Bd. 1:] Alfabetisk del. [Bd. 2:] Systematisk del. Det Kongelige Bibliotek, 1993, 514 s. (Specialhjalpemidler 27), der som titlen angiver dog kun omfatter de 2.800 på daværende tidspunkt opførelsesklare kor- og orkesterværker med stemmesæt til udlån. Siden ajourført i REX.

42 Biblioteket overtog i 2003-04 samlingen fra Danmarks Pædagogiske Universitets (tidl. Danmarks Lærerhøjskoles) Musikvidenskabelige Institut ved dettes nedlæggelse og ajourførte og supplerede denne samling med henblik på udlån, se Arsberetning 2004, 2005, s. 62.

43 Inge Bittmann: Catalogue of Giedde's Music Collection in the Royal Library. Det Kongelige Bibliotek: Edition Egtved. 1976, $198 \mathrm{~s}$.

44 Catalogue of the Rischel and Birket-Smith Collection of Guitar Music in the Royal Library of Copenhagen. Comp. by Jytte Torpp Larsson. Ed. by Peter Danner. Columbus, Ohio: Editions Orphée. 1989, 263 s. Samlingen erhvervedes i to omgange 1939 og 1952 og omfatter mere end 1.000 numre i både tryk og manuskript.

45 Polsk musik fra det 20. århundrede på Det kongelige Bibliotek. Samlet og red. af Susanne Sugar. Forord af Teresa Waskowska. Det Kongelige Bibliotek. 1990, 41 s. (Specialhjelpemidler 20). Opførelsesmateriale i alle genrer fra 94 , heraf 7 kvindelige komponister.

46 Se Niels Bo Foltmann \& Lisbeth Ahlgren Jensen: "Det Kongelige Bibliotek som udgiver af den musikalske kulturarv - belyst ved udgivelsen af Carl Nielsens musik", I: Umisteligt. Festskrift til Erland Kolding Nielsen. Red. af John T. Lauridsen \& Olaf Olsen. Det Kongelige Bibliotek: Museum Tusculanums Forlag, 2007, ss. 571-588. 
47 Se Niels Krabbe: "The Carl Nielsen Edition”, Carl Nielsen Studies (Publ. by the Royal Library), IV, 2009, ss. 88-106; samme: "Carl Nielsen Udgaven: En praktisk-videnskabelig udgave af komponistens samlede produktion", Arsberetning 1998, 1999, ss. 37-40, og årlige rapporter frem til 2008, jf. derefter note 84; endvidere samme: "The Carl Nielsen Edition", Nordic Music Editions. Symposium 1-2 September 2005. Org. by the Niels W. Gade Edition and the Carl Nielsen Edition. Proceedings, ed. by Niels Krabbe. The Royal Library, 2006, ss. 89-95. For den løbende udgivelse af de enkelte bind, se årsberetningernes publikationsoversigter. Bindantallet inkluderer paralleludgivelser af operaerne på dansk/engelsk og dansk/tysk, klaverudtog, og særudgaver af en række værker enkeltvis, bl.a. koncerterne. Alle værker kan nu downloades som pdffiler, se <www.kb.dk/en/nb/dcm/cnu/ download.html $>$.

48 Se John Fellow: "Carl Nielsen Brevudgaven”, Arsberetning 2003, 2004, s. 62 f. For udgivelsen af de enkelte bind, se arsberetningernes publikationsoversigter. Forordene/indledningerne til de enkelte bind kan ses her: <www.kb.dk/da/nb/ samling/ma/fokus/cnb.html >.

49 Ed. by Niels Bo Foltmann, Axel Teich Geertinger, Peter Hauge, Niels Krabbe, Bjarke Moe, Elly Bruunshuus Petersen. Se Axel Teich Geertinger: "Carl Nielsen Værkfortegnelsen (CNW)", Arsberetning 2014, 2015, s. 76f. Den findes på adressen <www.kb.dk/dcm/cnw/preface.xq >. En trykt brugsudgave udkommer i 2016.

50 Carl Nielsen Studies, publ. by the Royal Library, vol. I, ed. by David Fanning, Daniel Grimley \& Niels Krabbe, 2003, 188 s.; vol. II, ed. by [samme] \& Knud Ketting, 2005, 249 s.; vol. III, ed. by David Fanning, Daniel Grimley \& Niels Krabbe, 2008, 116 s.; vol. IV, ed. by [samme] \& Michael Fjeldsøe, 2009, 190 s.; vol. V, ed. by [samme], 2012, 393 s.

51 Kirsten Flensborg Petersen: "Carl Nielsen Bibliography 1985-1995”, Carl Nielsen Studies, vol. 1, ss. 169-180; samme: “... 1996-2003”, vol. II, ss. 234-248; samme: “... 2004-2007”, vol. III, ss. 102-110; samme: “... 2008”, vol. IV, ss. 186-188; Anne Ørbæk Jensen \& Niels Krabbe: “... 2009-2011", vol. V, ss. 385-89.

52 Nordic Music Editions. Symposium 1-2 September 2005. Org. by the Niels W. Gade Edition and the Carl Nielsen Edition. Proceedings, ed. by Niels Krabbe. The Royal Library, 2006, 105 s.

53 Med støtte fra Det Frie Forskningsråd og Sonning-Fonden. Konferencebidragene er publiceret i Carl Nielsen Studies, V, 2012, 393 s., med Niels Krabbe som ed.-in-chief, se ovf.

54 Bd. 1-3 udg. af Steen Pade [ \& Bendt Viinholt Nielsen]. Det Kongelige Bibliotek \& Samfundet til Udgivelse af Dansk Musik, 1993: Bd. 1: Rued Langgaard: Strygekvartet nr. 6. BVN 160; Bd. 2: Samme: Insektarium. 9 Fixerbilleder (for Piano). BVN 134. Afgrundsmusik. En Sonate for Klaver. BNV 169; Bd. 3: Samme: Strygekvartet nr. 2. BNV 145. Bd. 4 af Birgit Bjørnum. 1997: Knudåge Riisager: Musik for blaserkvintet opus 16. Alle med engelske paralleltitler. DCM's publikationsvirksomhed må siges at være en fortsættelse af bl.a. denne serie.

55 Se Niels Krabbe: "Hartmann Udgaven - den videnskabelige udgave af udvalgte værker af J.P.E. Hartmann”, Arsberetning 2002, 2003, s. 69f.; samme: "Hartmann Udgaven”, Arsberetning 2003, 2004, s. 64f.; samme: "J.P.E. Hartmanns opera Liden Kirsten i kritisk-videnskabelig udgave", Arsberetning 2005, 2006, s. 59f.; samme: "J.P.E. Hartmanns klavermusik i ny udgave", Arsberetning 2012, 2013, s. $78 \mathrm{f}$. For udgivelsen af de enkelte bind, se årsberetningernes publikationsoversigter. 
56 Om Niels W. Gade Udgaven, se Finn Egeland Hansen: "Niels W. Gades samlede værker - det hidtil største danske nodeudgivelsesprojekt", Magasin fra Det Kongelige Bibliotek, årg. 5:1, 1990, ss. 5-18; samme: "The Niels W. Gade Edition”, Nordic Music Editions. Symposium 1-2 September 2005. Org. by the Niels W. Gade Edition and the Carl Nielsen Edition. Proceedings, ed. by Niels Krabbe. The Royal Library, 2006, ss. 76-80. Udgaven er planlagt til at omfatte 39 bind. Senere forskningsbibliotekar, 2009-13 førstebibliotekar, cand.mag. Anne Ørbæk Jensen ansattes med støtte fra Statens Humanistiske Forskningsråd i Gade-Fondens regi som sekretær fra 1990 med at skabe overblik over manuskripter, breve m.v., ikke mindst internationalt i et særligt Gade-Arkiv, der nu er overdraget til Det Kongelige Bibliotek.

57 J.P.E. Hartmann og hans kreds. En komponistfamilies breve 1780-1900. Udg. med indledning og noter af Inger Sørensen. Bind 4: Breve i privateje. Det Kongelige Bibliotek: Museum Tusculanums Forlag. 2002. 623 s. Ill. (Danish Humanist Texts and Studies vol. 17:4).

58 Niels W. Gade og hans europeiske kreds. En brevveksling 1836-1891/ Niels W. Gade und sein europäischer Kreis. Ein Briefwechsel 1836-1891. Udg. af / Hrsg. von Inger Sørensen. Udg. af Det Kongelige Bibliotek \& Det Danske Sprog-og Litteraturselskab / Hrsg. von Der Königlichen Bibliothek \& Gesellschaft für Dänische Sprache und Literatur: I kommission hos / in Kommission bei Museum Tusculanum Press, 2008. Bd. 1-3, i alt 1.668 ss. Ill. (Danish Humanist Texts and Studies, vol. 36).

59 Sørensen, Inger (udg.): Et venskab. C.F.E. Hornemans korrespondance med Edvard Grieg. 2011.166 s. Ill. (Serien: Danish Humanist Texts and Studies, vol. 40). Dertil knytter sig dynastibiografien
Horneman. En kunstnerslegt. Museum Tusculanums Forlag. 2011, 397 s. Ill.

60 Udg. af / Herausgegeben von / Edited by Ole Kongsted. Serie A: Renaissancemusik. Vol. 1-2. 2001-02; titelskift fra bind 3 til Monumenta Musica Regionis Balticae / Denkmäler der Musik des Ostseeraum / Monuments of Music from the Baltic Sea Area: Series A: Monumenta Musica Regionis Balticae, Voc. Vol. 3-8. 2004-07; Series K: Monumenta Musica Regionis Balticae, Instr. Vol. 1. 2004; desuden som underserier af Capella Hafniensis Editions: Series B. Music of the Renaissance, Voc., Europe. Vol 1-2. 2005-09; Series D: Danish Contemporary Vocal Music. Vol 1-3, 2005-08.

61 The Offices and Masses of St. Knud Lavard († 1131) (Kiel, Univ. Libr. MS S.H. 8 $A .8^{\circ}$ ). Reproduced in facsimile, transcribed and edited by John Bergsagel. Volume 1: Facsimile. Foreword by Erland Kolding Nielsen. Volume 2: Edition with an essay on the historical background by Thomas Riis. Foreword by David Hiley. Published simultaneously by The Danish Centre for Music Publication of the Royal Library, Copenhagen, and the Institute of Medieval Music, Ottawa, Canada. 2010. xii, 245 pp.; xliv, 72 pp. Ill.

62 Se Erland Kolding Nielsen: "Internationalt videnskabeligt symposium 'Of Chronicles and Kings' på Det Kongelige Bibliotek", Arsberetning 2012, 2013, s. 133f. Konferencebidragene blev udgivet i 2015 i Of Chronicles and Kings. National Saints and The Emergence of Nation States in the High Middle Ages. Ed. by John Bergsagel, Thomas Riis \& David Hiley. Det Kongelige Bibliotek: Museum Tusculanum Press. 2015, 512 s. (Danish Humanist Texts and Studies, vol. 52).

63 Kronborg Motetterne. Tilegnet Frederik II og Dronning Sophie 1582. Udgivet i Anledning af Hendes Majestæt Dronning Margrethe II's Halvtredsårsdag 16.4.1990. Ved Ole Kongsted. Red. og tilrettelæg- 
gelse ved Jesper Düring Jørgensen og Erik Dal. Det Kongelige Bibliotek. 1990, 99 s. Storfol. Brugsudgave: Leonhard Lechner? “Kronborg-Motetterne". Udg. af Ole Kongsted. Det kongelige Bibliotek: Engstrøm \& Sødring. 1992, 17 s. (Musik i Danmark på Frederik II's tid VIII). Se også nedenfor under udstillinger.

64 Se herom Ole Kongsted: KronborgBrunnen und Kronborg-Motetten. Ein Notenfund des späten 16. Jahrbunderts aus Flensburg und seine Vorgeschichte. Kbh., Flensburg, Kiel: Gesellschaft für Flensburger Stadtgeschichte. 1991, 111 s. (Schriften der Gesellschaft für Flensburger Stadtgeschichte 41). Udg. som Beiheft til Kronborg Motetterne.

65 Heinrich Panofka: Ein musikalisches Stammbuch (Königliche Bibliothek Kopenhagen). Hrsg. von Eva-Brit Fanger $(\dagger)$. Red. von Elisabeth Th. Fritz-Hilscher. Tutzing: Hans Schneider. 2007. [2 bind:] Faksimile. 168 s. Kommentar und Katalog. 103 s. Indeholder autografer af Beethoven, Hummel, Berlioz, Paganini, Liszt, Schubert, David, Weber, Brahms, Schumann, Sarasate, Rubinstein, Wieniawski, Hartmann, Svendsen, Gade m.fl. Autografen til Schuberts Lied "Herbst" her er hovedkilden til denne sang.

66 Carl Nielsen til sin samtid. Artikler, foredrag, interview, presseindlag, varknoter og manuskripter. Udgivet af John Fellow. Det Kongelige Bibliotek: Carl Nielsen Udgaven: Gyldendal. 1999. 919 s. Ill. Indb. Bd. 1: 1891-1925. Bd. 2: 1926-1933. Bd. 3: Noter og registre.

67 En Musiker oplever den europaiske Kultur. Erindringer 1900-1939. Udg. af cand. mag. Eva Hvidt. Udk. 2016., se <www.kb.dk/da/nb/dcm/projekter/ klenau_tekster.html>.

68 Knudåge Riisager: Symfonien er død - musikken leve og andre essays. Med indledning af Sven Erik Werner og bibliografi over
Riisagers litterære arbejder. Udg. af Niels Krabbe. Det Kongelige Bibliotek. 1997, 179 s.

69 Per Nørgairds skrifter online. Udg. af Ivan Hansen. Online 2012, se <www.kb.dk/ $\mathrm{da} / \mathrm{nb} / \mathrm{dcm} /$ udgivelser/norgard $>$. Omfatter ca. 400 tekster.

70 Røllum-Larsen, Claus: Impulser i Københavns koncertrepertoire 1900-1935. Studier i presentationen af ny, iser udenlandsk instrumentalmusik. Det Kongelige Bibliotek: Museum Tusculanums Forlag. 2002. 2 bd., 310, 385 s. Ill. (Danish Humanist Texts and Studies vol. 25). [Rev. ph.d.afhandling ved Københavns Universitet].

71 Hansen, Finn Egeland: Layers of Musical Meaning. The Royal Library: Museum Tusculanum Press. 2006. xii, 336 s. Ill. (Danish Humanist Texts and Studies, vol. 33).

72 Reynolds, Anne-Marie: Carl Nielsen's Voice. His Songs in Context. Publ. by the Royal Library: Museum Tusculanums Forlag. 2010.371 s. Ill. (Danish Humanist Texts and Studies, vol. 38).

73 Fjeldsøe, Michael: Kulturradikalismens musik. [Disputats]. Det Kongelige Bibliotek: Museum Tusculanums Forlag. 2013, 829 s. (Danish Humanist Texts and Studies, vol. 45). [Disputats ved Københavns Universitet].

74 Røllum-Larsen, Claus: Knudige Riisager. Komponist og skribent. With an English Summary. Det Kongelige Bibliotek: Museum Tusculanums Forlag. 2015. Bind 1-2,811s. Cd indlagt (Danish Humanist Texts and Studies, vol. 49). Cd indlagt.

75 Musikvidenskabelige Kompositioner. Festskrift til Niels Krabbe 1941. 3. oktober. 2006. Red. af Anne Ørbæk Jensen, John T. Lauridsen, Erland Kolding Nielsen, Claus Røllum-Larsen under medvirken af Sofie Lene Bak, Jakob K. Meile. Det Kongelige Bibliotek: Museum Tusculanums Forlag. 2006. 754 s. Ill. (Danish Humanist Texts and Studies, vol. 34). 
76 A due. Musical Essays in Honour of / Musikalische Aufsätze zu Ehren von John D. Bergsagel \& Heinrich W. Schwab. Ed. by / Hrsg. von Ole Kongsted, Niels Krabbe, Michael Kube, Morten Michelsen \& Lisbeth Larsen. Publ. by the Royal Library $\&$ Section of Musicology, University of Copenhagen. On consignment at Museum Tusculanum Press. Copenhagen, 2008. 740 s. Ill. (Danish Humanist Texts and Studies, vol. 37).

77 Studia Musicologica Regionis Balticae. Vol. 1. Herausgegeben von Ole Kongsted. København: Capella Hafniensis Editions in Zusammenarbeit mit der Königlichen Bibliothek, Kopenhagen. 2011.304 s. Ill.

78 Hauge, Peter: The Temple of Music by Robert Fludd. Aldershot: Ashgate. 2011, 315 pp., ills. (Music Theory in Britain, 1500-1700: Critical Editions).

79 Koudal, Jens Henrik: For borgere og bønder. Stadsmusikantvasenet i Danmark ca. 1660-1800. [Dansk Folkemindesamling:] Museum Tusculanums Forlag. 2000, 836 s. Ill. [Disputats ved Københavns Universitet]. Forventes udg. på engelsk 2017.

80 Halskov Hansen, Lene: Balladesang og kadedans. To aspekter af dansk folkevisekultur. [Dansk Folkemindesamling:] Museum Tusculanums Forlag, 2015.370 s. Ill. Cd indlagt.

81 Ved hhv. seniorforsker, ph.d. Henrik Smith-Sivertsen, og forskerstipendiat, ph.d. Sanne Krogh Groth, begge Nationalsamlingsafdelingen. En større rapport af førstnævnte Et vaskeagte Myspacefenomen. Sys Bjerre i Netarkivet er under udgivelse.

82 Med titlen "Neue Sachlichkeit, Political Music, or Vernacular Avant-garde? Hanns Eisler and His Contemporaries", se <eisler2015.ku.dk>. Konferencen fandt sted d. 17.-19. september 2015. Hovedarrangør var professor, dr.phil. Michael Fjeldsøe, Københavns Universitet, fordum medarbejder ved CNU, se også ovf. note
73. I denne forbindelse foranstaltedes en udstillingskoncert i Dronningesalen med ikoniske værker fra 1930'rne, Bertold Brechts Rundköpfe und Spitzköpfe (1936) med Eislers musik i den originale version og Bernhard Christensens musik til Poul Henningsens dokumentarfilm Denmark (1935), for første gang opført ved en koncert. Konferencebidragene forventes udgivet af Hanns Eisler Gesellschaft, Berlin.

83 Finansieret i forholdet 3:1, senere 5:2 af hhv. Kulturministeriet og Carl Nielsen og Anne Marie Carl-Nielsens Legat. Alle trykkeudgifter er finansieret af 18 fonde og eksterne instanser.

84 Finansieret af Kulturministeriets tips- og lottomidler samt projektbevillinger fra bl.a. Carl Nielsen og Anne Marie CarlNielsens Legat, Weyse Fonden og senest Augustinus Fonden. Se Niels Krabbe: "Dansk Center for Musikudgivelse", Arsberetning 2009, 2010, s. 123f.; samme i: 2010, 2011, s. 120f.; 2011, 2012, s. 72f.; 2012, 2013, s. $76 f$. I almindelighed: Niels Bo Foltmann \& Niels Krabbe: DCM. Dansk Center for Musikudgivelse. Det Kongelige Bibliotek: Dansk Center for Musikudgivelse. 2011.25 s. Ill.

85 Fra webadressen: <www.kb.dk/da/kb/ $\mathrm{nb} / \mathrm{mta} / \mathrm{dcm} /$ udgivelser $>$. Udgivelserne kan løbende følges her og i Det Kongelige Biblioteks Arsberetning.

86 Centret blev i 2013 underkastet en international ekspertevaluering, se Axel Teich Geertinger: "Den internationale evaluering af Dansk Center for Musikudgivelse", Arsberetning 2013, 2014, s. 19f. Derefter udarbejdedes en "Strategisk plan 20142019 for Dansk Center for Musikudgivelse", trykt i: Arsberetning 2014, 2015, ss. 210-218 \& samlet publikationsliste pr. 1. okt. 2014, Sst., ss. 210-222.

87 J.P.E. Hartmann: Udvalgte Verker/Selected Works / Ausgewählte Werke. Udgivet af / 
Published by / herausgegeben von Hartmann Udgaven, Det Kongelige Bibliotek. Copenhagen: The Royal Library. 2002ff: Liden Kirsten Opus 44 / Little Kirsten Opus 44 / Klein Karin Opus 44. Udgivet af Inger Sørensen og Niels Krabbe. 2005. lxii, 446 s. Ill. Fol. Indb. (Serie IV, Bind $1 /$ Series IV, Vol. 1 / Serie IV, Band 1).

88 Peter Heise: Drot og Marsk. Tragisk Opera i fire akter / King and Marshal. Tragic Opera in Four Acts. Tekst af Christian Richardt. Udgivet af / edited by Niels Bo Foltmann, Peter Hauge, Niels Krabbe og Axel Teich Geertinger. Det Kongelige Bibliotek \& Edition S: Dansk Center for Musikudgivelse, 2012. 2 bind. xlvi, 869 ss. 2․ (DCM 12-13) - Klaverpartitur / Vocal Score ved / by Per Salo. 2012. xvi, 421 ss. $4^{\circ}$. (DCM 15). Distribution: Edition S, Gråbrødretorv 18, DK-1156, København $\mathrm{K}$ (www.edition-s.dk)

89 For baggrunden herfor, se Inger Sørensen: “C.F.E. Hornemans 'Aladdin'. En mishandlet opera”, Fund og Forskning i Det Kongelige Biblioteks Samlinger, 49, 2010, ss.286-315. Udgivelsen finansieres af Augustinus Fonden.

90 Se Anne Ørbæk Jensen \& Erland Kolding Nielsen: "Udgivelser af danske operapartiturer", Arsberetning 2013, 2014, ss. 36-39.

91 Zapolski Kvartetten 2000-2002, se Arsberetningerne 1999ff.

92 Beckett Fonden, Knud Højgaards Fond og Oticon Fonden. DR P2 er mediepartner. Se Anette Faaborg: "Siemens sponsorerer nyt ensemble til Diamanten", Arsberetning 2004, 2005, s. $104 \mathrm{f}$. Om ensemblet i 2015, se <www.kb.dk/da/ $\mathrm{dia} / \mathrm{musik} /$ ensemblet $>$.

93 Finansieret af A.P. Møller og Hustru Chastine Mærsk McKinney Møllers Fond, Augustinus Fonden, BeckettFonden, Carl Nielsen og Anne Marie Carl-Nielsens Legat og Aage og Johanne Louis-Hansens Fond. Alle runder blev streamet og finalen fjernsynsoptaget.
Om konkurrencen i almindelighed, se $<w w w . c a r l n i e l s e n i n t e r n a t i o n a l . d k>$ og i bibliotekets regi <www.kb.dk/da/dia/ musik/2015/151016_carlnielsen.html>.

94 Cd'er: J.P.E. Hartmann: Piano Music. Nina Gade (piano). Dacapo. 2000; Peter Tjaikovskij: Svanesøen. Det Kongelige Kapel / dirigent: Michael Schønwandt. Dacapo. 2000; Carl Nielsen: Sange. Michael Kristensen (tenor) \& Ulrich Sterk (klaver). Naxos. 2001; C.E.F. Weyse: Symphonies 1 \& 7. Concerto Copenhagen / dirigent: Lars Ulrik Mortensen. Olufsen Records. 2001; C.E.F. Weyse: Morgen- og aftensange. Dacapo 2006; Fra Hojskolesangbogen. Signe Asmussen (sopran) \& Ulrik Sterk (klaver). Dacapo 2006.

95 Cd'er: Carl Nielsen: Chamber Music. DiamantEnsemblet. Vol. 1-2. Dacapo, 2007. Carl Nielsen: Complete Piano Works. Christina Bjørkøe, piano. Vol. 1-2. Pladeselskabet CPO, Georgsmarienhütte, Tyskland. 2008.

96 Cd: DiamantEnsemblet plays Dvořák and Spohr [Hhv. Serenade for 10 blæsere, cello og kontrabas, d-mol, op. $44 \&$ Nonet for violin, viola, violoncel, kontrabas, fløjte, obo, klarinet, fagot og horn, F-dur, op. 31]. HNH International, 2006. Om ensemblets cd'er, se <www.kb.dk/da/dia/ musik/ensemblet/cd.html>.

97 Et udvalg på 20 blev i 2003 udgivet af Det Kongelige Bibliotek på cd'en Fuzzy: Kata$\log$ / Catalogue. Uddrag af "Musik i Skåret" / Extracts from "Music at One". Booklet, [44 s.] billeder og beskrivelser på dansk og engelsk af de 20 "skatte", der er udgangspunktet og inspirationen for komponistens musikstykker, samt hans kommentarer til musikkens forhold til disse.

98 Se: Musik og danskhed. Fem faglige bidrag til debatten om nationalitet. C.A. Reitzels Forlag 2005. 129 s. (Folkemindesamlingens Kulturstudier 5).

$99 \mathrm{Se}<$ blogs.kb.dk/NB/entry/min_musik_ din_musik_hvad $>$. 
100 Se tidsskriftet Kulturstudier, 2015:2, 153 s. [Temanummer om musik og identitet].

101 I samarbejde med Odense Bys Museer.

102 Se note 1. Cd'en finansieredes af Kulturministeriet, Carl Nielsen og Anne Marie Carl-Nielsens Legat og Oticon Fonden og tryktes i 40.000 eksemplarer.

103 Katalog over Det kongelige Biblioteks permanente Udstilling. Græbes Bogtrykkeri. 1908, 116 s., se afsnittet "Musik i Skrift og Tryk", nr. 711-744, ss. 84-88.

104 De mest værdifulde bøger og håndskrifter blev evakueret til bestemte kirkelofter på Sjælland og Lolland, for musikmanuskripterne se Sven Lunn: "Sikringen af Det kgl. Biblioteks danske Musikmanuskripter", Levende musik, 2. årg. nr. 5 , 1943, ss. 1-6.

105 Red. af forskningsbibliotekar, mag.art. Inge Henriksen, Musikafdelingen.

106 Red. af Musikafdelingen.

107 Red. af forskningsbibliotekar, cand.phil. Inger Sørensen, Danmarks Lærerhøjskoles Bibliotek.

108 Red. af Langgaard-forskeren, bibliotekar Bendt Viinholt Nielsen, Dansk Musikinformationscenter.

109 Red. af professor, dr.phil. et habil. Heinrich W. Schwab, Kiels Universitet i samarbejde med Bibliothek der Hansestadt Lübeck og Schleswig-Holsteinisches Landesbibliothek, Kiel. Udstillingen vistes i København november 1995-januar 1996, i Lübeck marts-april 1996 og i Kiel maj-juli 1996. Katalogbog: Heinrich W. Schwab: Friedrich Ludwig Aemilius Kunzen (1761-1817). Stationen seines Lebens und Wirkens. Ausstellung aus Anlass des Jübiläums der Berufung zum Musikdirektor der Königlich dänischen Hofkapelle im Jahre 1795. Heide in Holstein: Westholsteinische Verlagsanstalt Boyens \& Co. 1995, 224 s. (Schriften der Schleswig-Holsteinischen Landesbibliothek 21).
110 Red. af Musikafdelingen. Se også udgivelsen af hans skrifter og hans blæserkvintet $\mathrm{i}$ den anledning, note 54 og 68 .

111 Titel: "Festmusik fra Renaissancen". Dansk/tysk katalogbog: Festmusik fra Renaissancen. En udstilling arrangeret $\mathrm{i}$ samarbejde mellem Dansk Selskab for Musikforskning, Det nationalhistoriske Museum på Frederiksborg \& Det kongelige Bibliotek. Katalog ved Ole Kongsted, Harald Ilsøe, Steffen Heiberg \& Gerhard Kraack. Red. Jesper Düring Jørgensen. Det kongelige Bibliotek. 1990, $80 \mathrm{~s}$.

112 Kronborg Motetterne Tilegnet Frederik II og Dronning Sophie 1582. Udgivet i Anledning af Hendes Majestæt Dronning Margrethe II's Halvtredsårsdag 16.4.1990. Ved Ole Kongsted. Red. og tilrettelæggelse ved Jesper Düring Jørgensen og Erik Dal. Det Kongelige Bibliotek. 1990, 99 s. Storfol.

113 "J.P.E. Hartmann - komponist og samlingspunkt gennem et århundrede". Red. af forskningsbibliotekarerne, cand.mag. Anne Ørbæk Jensen og mag.art. Claus Røllum-Larsen, Det Kongelige Bibliotek, og cand.phil. Inger Sørensen, Danmarks Pædagogiske Bibliotek, se Arsberetning 2000, 2001, s. 52.

114 "Wahlverwandtschaften. Zwei Jahrhunderte musikalischer Wechselwirkungen zwischen Dänemark und Deutschland", red. i samarbejde med Niedersächsische Staats- und Universitätsbibliothek, Göttingen, af forskningsbibliotekarerne, cand.mag. Anne Ørbæk Jensen og mag. art. Claus Røllum-Larsen, Det Kongelige Bibliotek, og cand.phil. Inger Sørensen, Danmarks Pædagogiske Bibliotek, se Niels Krabbe: "Wahlverwandtschaften - udstilling i Göttingen om dansk-tyske musikrelationer", Arsberetning 2004, 2005, s. 68f. Katalogbog: Anne Ørbæk Jensen, Claus Røllum-Larsen \& Inger Sørensen: Wablverwandtschaften. Zwei Jahrhunderte musikalischer Wechsel- 
wirkungen zwischen Dänemark und Deutschland. Redaktion: Niels Krabbe. Det Kongelige Bibliothek. 2004, 118 s. (Göttinger Bibliotheksschriften 28).

115 "Over grænsen. Forbindelser mellem dansk og tysk musikliv 1760-1914”, se Arsberetning 2007, 2008, s. 68f. Hertil: Over gransen. Forbindelser mellem dansk og tysk musikliv 1760-1914. Genstandstekster. Red.: Anne Ørbæk Jensen, Claus Røllum-Larsen og Inger Sørensen. 2007. 131 s. Også på engelsk.

116 "Carl Nielsen - et stridens æble?", red. af forskningsbibliotekarerne, cand.mag. Anne Ørbæk Jensen, mag.art. Claus Røllum-Larsen \& førstebibliotekar, cand. mag. Niels Krabbe. Katalogbog: Carl Nielsen - et stridens able? / Carl Nielsen - an Apple of Contention? Red. Niels Krabbe, Claus Røllum-Larsen og Anne Ørbæk Jensen. Udg. af Det Kongelige Bibliotek. 2009. [94 s.]

117 Fejringen skete bl.a. i den tidligere universitetsbibliotekssal over Trinitatis Kirke ved Rundetårn, hvor Per Nørgaards (f. 1931) 8. strygekvartet blev uropført af Kontrakvartetten ved åbningen af udstillingen "Kongelige og Kostbart Klenodier fra kongernes bibliotek", se Arsberetning 1993, 1994, s. 2.
118 Poul Ruders' (f. 1949) Concerto for oboe and small orchestra, se Arsberetning 1999, 2000, s. 37.

119 Projektet "Musik i Skåret", planlagt i 1999, hvortil bestiltes værket KATALOG af Jens Wilhelm Pedersen (f. 1939), bedre kendt under navnet Fuzzy, der består af 52 ugedagsstykker af 3-4 minutters varighed, komponeret over bibliotekets skatte, se Niels Krabbe: "Musik i Skåret - 31/2 times musik i Atriet", Arsberetning 2002, 2003, s. 13 f. Projektet og værket blev til med støtte fra År 2000-Fonden og Kulturministeriet, se også note 97.

120 Komponistens (f. 1948) 1. strygekvartet uropførtes ved en koncert i anledning af hans 40-års komponistjubilæum i Dronningesalen d. 27.9.2014. Om erhvervelsen, se Erland Kolding Nielsen: "Originalpartituret til en ny nationalopera erhvervet. Bo Holtens Livlagens besøg 2009”, Arsberetning 2011, 2012, s. $74 \mathrm{f}$.

121 Erland Kolding Nielsen: "Postscript / Efterskrift” [om ideer, koncept og udvikling af opgaver i det første årti efter 1999], The Architecture of the Royal Library / Det Kongelige Biblioteks arkitektur. Udg. af schmidt hammer lassen architects. 2. udg. 2011, ss. 131-37. 